\title{
An Overview of Characterization and Identification of Soft Rot Bacterium Erwinia in Some Vegetable Crops
}

\section{*OPARA Emma Umunna and ASUQUO Aniebiet Austin}

\begin{abstract}
Department of Plant Health Management, Michael Okpara University of Agriculture, Umudike, Abia State.
\end{abstract}

\section{ARTICLE INFO}

Article No.: 041916078

Type: Review

DOI: 10.15580/GJBS.2016.3.041916078

Submitted: $19 / 04 / 2016$

Accepted: 25/04/2016

Published: $27 / 06 / 2016$

${ }^{*}$ Corresponding Author

Opara Emma Umunna

E-mail: euopara22@gmail.com

Keywords:

Isolation, microbes, Soft Rot, pathogen

Erwinia caratovora, pecteolytic

enzymes
Vegetables play an important role in human nutrition and diet by supplying the much needed vitamins, minerals, and fibers. However, this important contributor to human diet is constraint by challenges especially rotting caused by phytopathogens. Erwinia species is one of the most destructive diseases threatening vegetables and resulting in the decay of the produce both in the field, storage and on transit. The soft rot pathogen has a wide host range and attack crops of almost all families causing greater economic losses than any other bacterial disease. The pathogen penetrates its host basically through wounds and natural openings such as stomata, lenticels and hydathodes and releases an arsenal of plant cell-wall degrading enzymes such as cellulose, zylanase, polygalacturanase (PG) and pectin-methyl esterases (PME) causing the maceration of the middle lamella and subsequently cell death. Decay is favoured by high temperature and humidity. Transmission is by water, insects and from infected plants to uninfected plants especially during harvesting and storage when uninfected produce are exposed to contamination by infected ones. This article provides first-hand information to students, researchers and agriculturists about the soft rot pathogen, its mode of action, predisposing factors, host range, means of transmission and control measures. 


\section{INTRODUCTION}

Erwinia belongs to the family Enterobacteriaceae and to the genus Erwinia, containing mostly plant pathogenic species which was named after the famous plant pathologist, Erwin Frink Smith (Kharayat and Singh, 2015). It contains gram-negative bacteria related to Escherichia coli, Shigella, Salmonella and Yersinia. They are primarily rod-shaped bacteria. Erwinia species which most commonly attack vegetables belong to the Caratovora group or soft rot group. Erwinia carotovora is a typical species of this genus which is a rod shaped bacterium that was named after the crop of carrots from which it was first isolated. The bacterium infects a variety of vegetables and plants including carrots, potatoes, cucumbers, onions, tomatoes, lettuce and ornamental plants like iris (Wood, 1998). The three commercially important soft rot Erwinia are Erwinia carotovora pv. carotovora, Erwinia chrysanthemi and Erwinia carotovora pv. atroseptica, which causes black leg disease of potato and other commercially important crops (Czajkowski et al., 2009; Rahmanifar et al., 2012). Among these bacteria, Erwinia atroseptica is mainly restricted to temperate regions, whereas Erwinia carotovora is distributed in temperate and tropical zones worldwide and Erwinia chrysanthemi is found in (sub) tropical as well as in warm temperate regions (He'lias et al., 2000). As a major problem in agriculture, the microbes ceaselessly invade crops of potatoes and other vegetables in the fields or in storage and cause plant tissues to become soft and watery which eventually turn slimy and foul-smelling (Bell et al., 2004; Wood, 1998).

\section{Ecology of the Soft Rot Bacteria (Erwinia)}

Erwinia soft rot is one of the most destructive diseases of vegetables and occurs worldwide wherever fleshy storage tissues of vegetables and ornamentals are found. It causes a greater total loss of produce than any other bacterial disease. The disease can be found on crops in the field, in transit, in storage and during marketing; resulting in great economic losses (Agrios, 2006; Bhat et al., 2010). In addition to infected plants, these widespread microbes can also be found in soil, guts of insects and bodies of water introduced by, runoff into rivers and dumping of infected potatoes into water bodies ( Pe'rombelon 2000).

\section{Scientific Classification of the Soft Rot Pathogen (Erwinia)}

$\begin{array}{ll}\text { Kingdom } & \text { Bacteria } \\ \text { Phylum } & \text { Proteobacteria } \\ \text { Class } & \text { Gamma-proteobacteria } \\ \text { Order } & \text { Enterobacteriales } \\ \text { Family } & \text { Enterobacteriaceae } \\ \text { Genus } & \text { Erwinia } \\ \text { Species } & \text { E. caratovora }\end{array}$

\section{Disease Symptoms Caused By the Species Erwinia caratovora}

The foliar symptoms most commonly associated with the erwinia group as described by Lumb et al., (1986) is a wilt of the top leaves with subsequent desiccation around the margins and eventually of the entire leaves. These symptoms eventually spread to the lower leaves and, in extreme cases, the whole plant or stem dries out. Symptoms of soft rot on tubers, as described by Powelson and Franc (2001), range from a slight vascular discolouration to complete decay. Lesions commonly first develop in lenticels, at the site of stolon attachment or in wounds. Affected tuber tissue is cream- to tancoloured and is soft and granular. Brown to black pigments often develops at the margins of decayed tissue (Elphinestone and John, 2010).

On onions, bacterial soft rot symptoms often appear as a soft, watery rot of individual scales that may advance and rot the entire bulb. A foul-smelling viscous fluid oozes from the neck when infected bulbs are squeezed (Howard and David, 2007). Agrios, (2006), reported that cruciferous plants and onions when infected by soft rot bacteria, almost always give off a repulsive odor. 


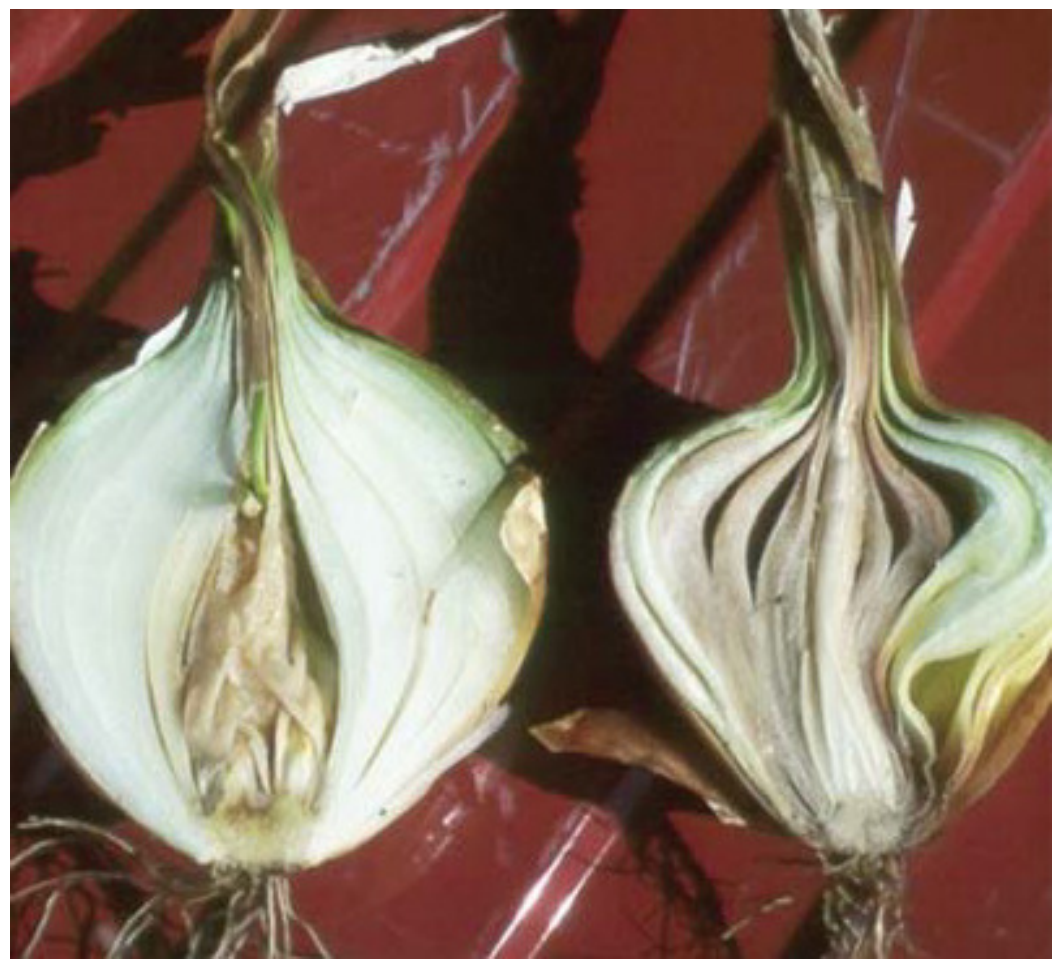

Figure 1: Symptom of Erwinia soft rot on onion bulb

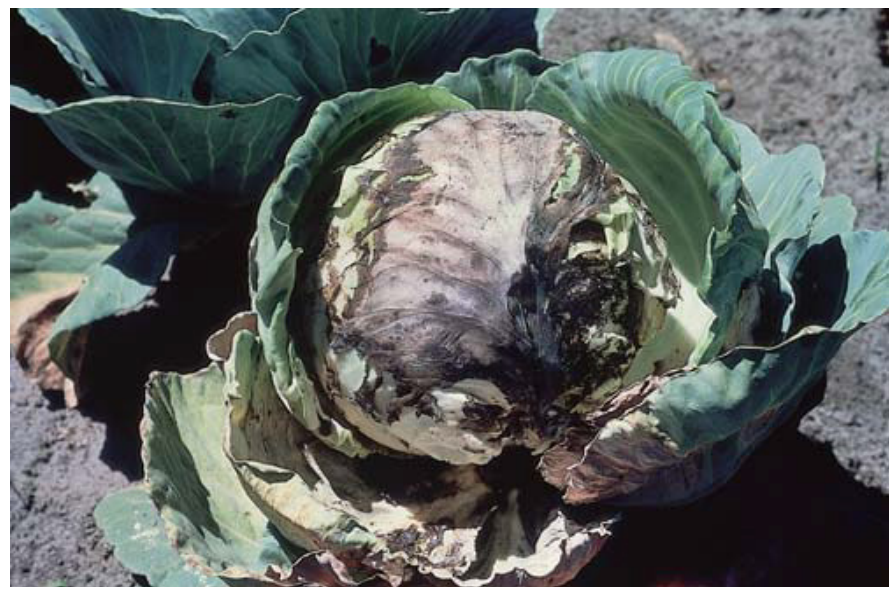

Figure 2: Cabbage head showing symptom of Erwinia soft rot

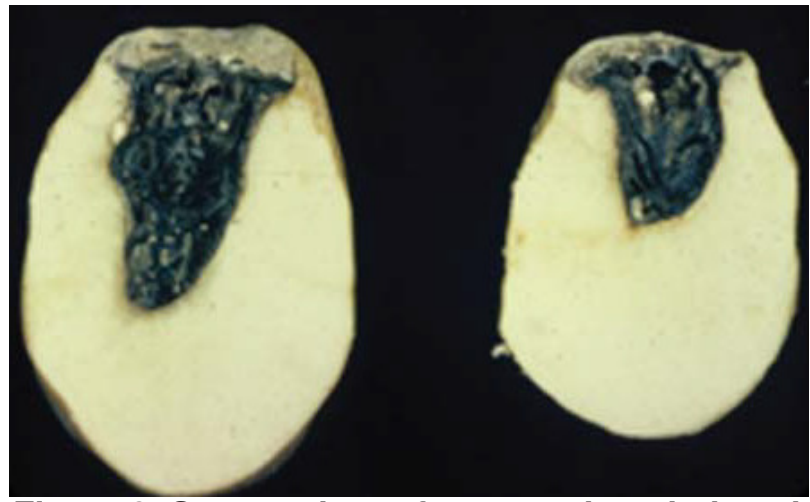

Figure 3: Stem-end rot of potato tubers induced by Erwinia atroseptica 


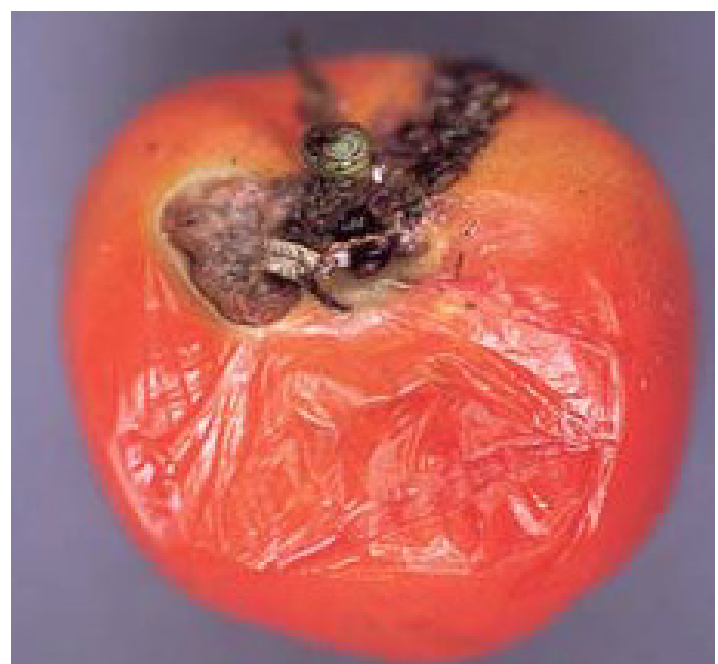

Figure 4: Erwinia soft rot on tomato

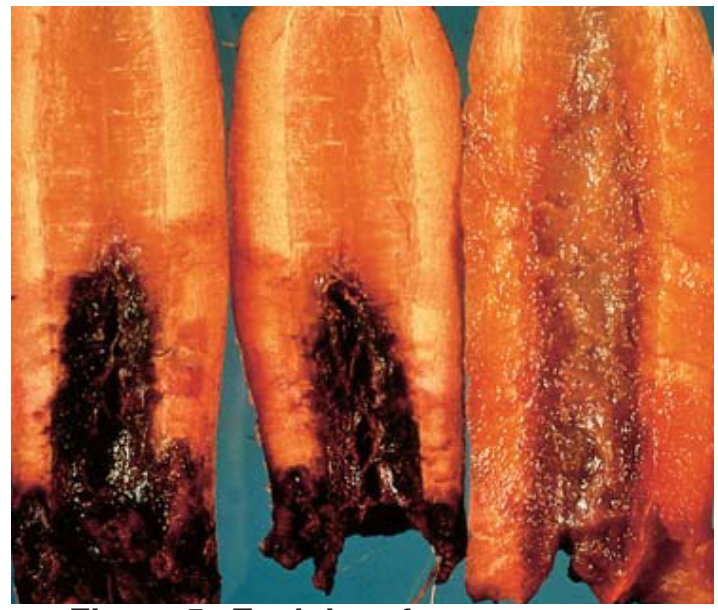

Figure 5: Erwinia soft rot on carrots

\section{Pathology of the Soft Rot Erwinia}

Erwinia carotovora is a plant pathogen that causes cell death through the degradation of succulent fleshy plant organs such as roots, tubers, stem cuttings and thick leaves by creating an osmotically fragile cell. This is achieved through the production of Plant cell walldegrading enzymes (PCWDEs) (Bell et al., 2004) such as extracellular pectic enzymes and cellulase that break down pectin and cellulose respectively. Enzymes that hydrolyze the middle lamella of host tissue in the development of soft rot were studied in detail by (Amadioha, 2012; Oladoye et al., 2013). These authors reported that spoilage organisms produce extra-cellular enzymes such as amylases, cellulase, zylanases, polygalacturanases (PG) and pectin-methyl esterases (PME) which degrade cell wall components of susceptible produce and dissolve the middle lamella, which serves to cement the adjacent cell walls together and thus loosen the cells from one another leading to emission of foul odour and water. The by-product of the bacterial growth also set ex-osmosis of liquid containing sugar and salts from within the cells to the inter-cellular spaces, where it serve as a source of food for further bacterial growth. The continuation of this process accounts for the watery condition and for the loss of consistency of the decayed tissue. Direct involvement of pectic and cellulolytic enzymes produced by rot pathogens have also been reported by Garber et al., 1990; Walker et al., 1994. According to Ugwoke et al., 2008, the rot incitants in cocoyam tubers also possess cellulolytic and pectinolytic enzymes capable of degrading cell wall polymers and making available carbon sources to the invading pathogen. However, Amadioha (1997) established that optimum production of $P G$ and PME occurred under slightly alkaline conditions whereas acid condition favoured the production of cellulases. He pointed out that PG was primarily 
responsible for tissue maceration and cell death of potato tissues whereas cellulases seem to play secondary role in the process.

When soft rot bacteria enter through wounds or natural openings, they feed and multiply at first on the liquid released by the broken cells on the wound surface, and then they produce increased amounts of pecteolytic enzymes that break down pectic substance of the middle lamella resulting in maceration of the tissue (Agrios, 2006; Jones, 1901; Bhat et al., 2010). Bacteria continue to move and multiply in inter-cellular space, as a result cells are plasmolyzed, or collapsed, and die in the intercellular spaces, while their enzymes advance ahead of them and prepare the tissue for further invasion.

It also behaves as a vascular wilt pathogen, colonizing the xylem and becoming systemic within the plant. This latter aspect is the most alarming when vegetative propagation is involved. The pathogen can remain latent or inactive in stock plants (ornamentals, bananas) and can thus be spread in cuttings when later reactivated. Infected tubers are an important source of inoculum for potatoes, either by plant to plant spread or insect vectors to plant, thus leading to soft-rot diseases of many plants and vegetables that eventually become metabolized into slimy and foul smelling as in rotten Irish potato (Wood, 1998). Yield losses up to $98.8 \%$ have been experienced under artificial epiphytotics or epidemics of plant diseases (Thinda and Payakab, 1985).
The bacterium is able to survive in the soil (on plant debris), so that infestation remains between two crops. The decay is aggravated when high relative humidity is coupled with high temperature of about $30^{\circ} \mathrm{C}$ which results in faster rate of multiplication of the pathogen (Nahunnara, 2008; Bhat et al., 2010).

\section{ISOLATION OF THE SOFT ROT BACTERIA (Erwinia carotovora)}

Erwinia spp may be isolated from rotting stem tissue or tubers. The isolation procedures are similar to those used for other plant pathogenic bacteria;

- Surface sterilized the diseased plant part by mopping the entire surface with cotton wool moistened with $1 \%$ sodium hypochlorite solution $(\mathrm{NaOcl})$

- Cut small sections (1-2mm) of the infected plant part from the margin between diseased and healthy tissue with a sterile scalpel

- Place in a drop of sterile water

- Macerate tissue apart with sterile scalpel

- Allow to stand for 10-15 minutes

- With a wire loop, streak a loopful $(0.5 \mathrm{ml})$ of the suspension onto dry plates of nutrient agar

- Incubate plates at $25^{\circ} \mathrm{C}$ for at least 4hours

- Incubated plates should be examined daily for the appearance of bacterial colonies

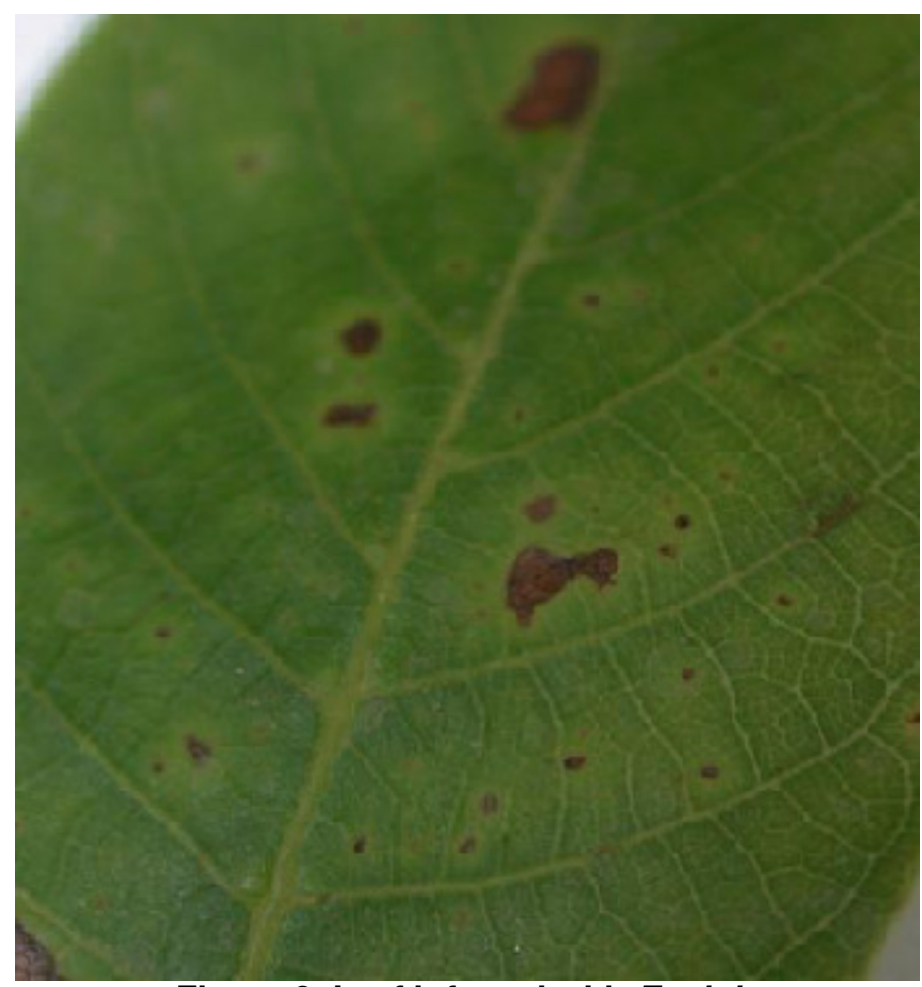

Figure 6: Leaf infected with Erwinia 


\section{Morphological Identification of Erwinia caratovora}

Erwinia carotovora is a Gram-negative, rod-shaped bacterium that lives alone or aggregates into pairs and chains. Non-spore forming and peritrichously flagellated, it is a facultative anaerobe that is catalase negative and oxidase positive (Agrios, 2006; Pérombelon, 2005). Erwinia carotovora produces a number of extracellular plant cell wall degrading enzymes such as pectic enzymes that degrade pectin, cellulase that degrades cellulose, hemicellulases, arabanases, cyanoses and a protease. As a mesophilic bacterium, Erwinia carotovora thrives the most in the temperature range between 27 and 30 degrees Celsius (Pe'rombelon, 2000). The colonies of E. caratovora pv. caratovora and pv. atroseptica on most media are greyish-white to creamy -white, smooth, round, glistening and slightly raised and visible on isolation plates after about 24 hours. Colonies of E. chrysanthemi on most media are greyish-white to creamy -white, smooth, round, with margins becoming undulate to feathery, flat to slightly raised (Gupta and Thind, 2006, Bradbury, 1977a, 1977b).

\section{Biochemical Characteristics of Erwinia Caratovora}

The biochemical characteristics which are useful in the differentiation of soft-rotting species of Erwinia are ability to grow at $37^{\circ} \mathrm{C}$, production of reducing substances from sucrose; production of acid from maltose, a-methyl glucoside, lactose and trehalose; growth in 5\% Nacl; production of indole, lecithinase and phosphatase; and sensitivity to erythromycin. Biochemical tests useful for the differentiation of members of the "caratovora" group are given in the table below

Table 1: Biochemical Tests for the Differentiation of the Soft-Rot Erwinia Species

\begin{tabular}{|c|c|c|c|}
\hline Test & Ecc & Eca & Ech \\
\hline Production of blue pigment on PDA & - & - & $\mathrm{v}$ \\
\hline Growth at $37^{\circ} \mathrm{C}$ & + & - & + \\
\hline Reducing substances from sucrose & - & + & - \\
\hline \multicolumn{4}{|l|}{ Acid Production in seven days from } \\
\hline Maltose & V & + & - \\
\hline Trehalose & + & + & - \\
\hline lactose & + & + & - \\
\hline Dulcitol & - & - & - \\
\hline a-methyl glucoside & - & + & - \\
\hline Growth in $5 \% \mathrm{NaCl}$ & + & + & - \\
\hline \multicolumn{4}{|l|}{ Production of } \\
\hline Indole & - & - & + \\
\hline Phosphatase & - & - & + \\
\hline Sensitivity to erythromycin & - & - & + \\
\hline
\end{tabular}

Adapted from Hyman (1995).

Ecc, E. caratovora pv. caratovora; Eca, E. caratovora pv. atroseptica; Ech, E. caratovora pv. chrysanthemi

\section{Some Soft Rot Diseases Caused By Erwinia Species}

\section{Disease and host}

Bacterial soft rot of cabbage

Bacterial soft rot of potato

Bacterial soft rot of celery

Bacterial soft rot of onions

Barn rots of tobacco

Blackleg of potato

Bacterial root rot of sugar-beet

Fruit collapse of pineapple

Foot rot of rice

\section{Causal agent}

E.caratovora pv. caratovora

E.caratovora pv. caratovora

E.caratovora pv. caratovora

E.caratovora pv. chrysanthemi

E.caratovora pv. caratovora

E.caratovora pv. atroseptica

E.caratovora pv. atroseptica

E.caratovora pv. chrysanthemi

E.caratovora pv. chrysanthemi 
Stalk rot of maize

Bacterial mottle of sugarcane
E.caratovora pv. chrysanthemi

E.caratovora pv. chrysanthemi

\section{Modes of Transmission of the Pathogen}

Methods of dissemination of Erwinia are quite varied. One is plant to plant infection. Most potato seed tubers have some form of soft rot Erwinia on their skin from the mother tuber rotting. Upon injury to the tuber, the infection takes over and quickly rots the tuber. Often, this takes many others with it, especially in industrial harvesting, where a large quantity would be exposed to a rotting tuber. Farrar et al., (2009) reported how easily tuber to tuber transmission occurs that during the lifting and harvesting of potatoes, tubers can be smeared with soft rot bacteria from decayed seed pieces. At the packing shed, potatoes are first dumped into a wash tank to clean them. Surface bacteria can be pushed into lenticels by hydrostatic pressure (exerted by water) in the water tanks. Once inside the lenticel tissues, the bacteria multiply and cause lenticel rot (Bartz and Kelman, 1985).

E. carotovora can survive in an insect's gut for several hours, insects and related organisms, such as mites, are frequently involved in the transmission of plant pathogens from one plant organ to another on which then the pathogens multiply and cause rot disease, and therefore can easily be transmitted from plant to plant this way. Equally important is that insects can transmit pathogens among plants from one field to another, in many cases even when the fields are several to many miles apart. Almost all types of pathogens, that is, fungi, bacteria, viruses, nematodes, and protozoa, can be transmitted by insects (Agrios, 1997).

Insects transmit pathogens, such as many fungi and bacteria, in three main ways; mostly externally on their legs, mouthparts, and bodies;

1) Many insects transmit bacterial and fungal spores passively by feeding in or walking through an infected plant area that has on its surface plant pathogenic bacteria or fungal spores as a result of the infection. The bacteria and spores are often sticky, cling to the insect as it moves about, and are carried by it to other plants or parts of the same plant where they may start a new infection.

2) Some insects transmit certain bacteria, fungi, and viruses by feeding on infected plant tissues and carrying the pathogen on their mouthparts as they visit and feed on other plants or plant parts.

3) Several insects transmit specific viruses, phytoplasmas, protozoa, nematodes, and xylem-and phloem-inhabiting bacteria by ingesting (sucking) the pathogen with the plant sap they eat. Subsequently, the pathogen circulates through the body of the insect until, with or without further multiplication in the insect; the pathogen reaches the salivary glands and the mouthparts of the insect through which it is injected into the next plant on which the insect feeds (Agrios, 1997). The relation of insect with bacterial soft rot disease has been worked out and first reported by Leach (1926). Leach $(1925,1926)$ showed that the seed-corn maggot (Hylemyia cili-crura Rond.) plays an active part in the spread and development of potato blackleg both in storage and in the field. According to Leach (1926), a symbiotic relationship exists between the pathogenic organism of blackleg and the seed-corn maggot, the eggs while being deposited in the soil may be-come contaminated by pathogenic bacteria, and the young maggots may introduce this inoculum into the planted potato seed pieces. These pathogens and other microorganisms are present in the internal portion of the pupal and larval stages as well as on the surface of the eggs (Leach, 1930; 1933). In a related study, Leach ( 1927), found that two insects (Scaptomyza graminum and Elachiptera costata) are common agents of inoculation of celery heart rot also caused by Erwinia carotovora the cause of blackleg and seed-piece decay in the potato. Johnson (1930) described the relation of cabbage maggot and other insects to spread as well as development of soft rot in Cruciferae. Similar observations were recorded by Bond (1939) while working on blackleg of potato. Kloepper et al., (1981) reported that adult fruit flies (Drosophila melanogaster Meig) artificially contaminated with $E$. caratovora and $E$. caratovora atroseptica readily transmitted the bacteria to plants in the field that have been injured by crushing the stem.

Another mode of transport of the pathogen is via aerosols. When rain falls on either diseased plants or any other thing that is contaminated with Erwinia, an aerosol can be created where the bacteria is airborne in water. Around $50 \%$ can only survive as an aerosol for 510 minutes, but this is long enough to travel many miles in a brisk wind. It has also recently been shown that $E$. carotovora can be found in water. It has been found "in surface waters, streams, rivers, lakes, reservoirs, ditches, and the sea in many countries (Perombelon, 2000).

\section{Host Range of the Soft Rot Pathogen (Erwinia)}

The species is a plant pathogen with a diverse host range, including many agriculturally and scientifically important plant species such as carrot, potato, tomato, leafy greens, squash and other cucurbits, onion, green peppers, African violets etc. (Perombelon, 2002; Toth et al., 2003; Agrios, 2006; Howard and David, 2007; Garba et al., 2014). Erinle (1981) and Apeyuan (2000) reported that the pathogen is mostly common on plants that have fleshly storage tissues e.g. root, tuber, fruits such as tomato, eggplant, succulent stem, stalk or leaves such as lettuce and cabbage. Erwinia spp causes rots on 
stored tubers as well as on a wide range of other plants as tomatoes, pepper and onions (Hadas et al., 2001; Erinle, 1975). Arsenijevic (1978) reported it on sunflower, cactus, cabbage, pineapple, pepper, tomato, carrot and cauliflower. Also, Tsuyama (1978) reported that it is pathogenic on tobacco plant. Robert and Blanchette (1994) established that Erwinia spp can degrade lignified cell walls of wood known to be resistant to aggressive brown and white rot fungi, Eusideroxoylon zwageri, the world's most durable timber. Walker, (1998) has reviewed bacterial soft rot in the crucifers and reports that if not all but many crucifers are susceptible to bacterial soft rot which include cabbage, cauliflower, brussel sprouts, turnip, radish, rape, etc. Ismail et al., (2012) reported that the pathogen could infect fruits of apricot, apple, olive, lemon, squash, eggplant, garlic, onion, radish, carrot, sweet potato and turnip The host range includes genera from all the plant families of vegetables, fruits and ornamentals, nearly about sixty four plant species are susceptible to the disease (Anonymous, 1990). Phokim et al. (2006) conducted a DNA polymerase chain reaction assay using $Y 1$ and $Y 2$ primers specific to amplify 434 bp pectate lyase gene $(\mathrm{Pel})$ of $E$. carotovora from ten different varieties of vegetables viz., cabbage, cauliflower, Chinese cabbage, pakchoi, spinach, carrot, Chinese radish, cucumber, tomato and asparagus. The result showed that primers Y1 and Y2 detected all isolates and were classified as soft rot Erwinia group.

Rajeh and Khlaif (2000) during a survey collected eighty seven isolates of bacteria from soft rot symptoms from different vegetable crops including, cabbage, cauliflower, lettuce, onion, pepper, potato, spinach, sweet melon and tomato. Upon identification it was observed that the cause of soft rot in all the vegetables is $E$. carotovora. Bradbury, 1986 has reviewed the host range of $E$. carotovora pv. carotovora and reported that $B$. chinensis (Chinese cabbage) B.o var acephala (kale), Cucumis sativus, Delphinum ajacis, Glycine max, Helianthus tuberosus, Lupinus sp., Phaseolus vulgaris, Nicotiane tabacum, are its hosts while Solunum tuborosum is the main host of $E$. carotovora pv. atroseptica, but natural infection has also been reported for this sub- specie on cauliflower, cabbage, iris and tomato. E. carotovora have been reportedly causing severe post-harvest soft rot and stem end decay that result in losses to pepper (Sherman and Allen, 1983). It is a very economically important pathogen in terms of postharvest losses, and a common cause of decay in stored fruits and vegetables (Agrios, 2006).

\section{Control of the soft rot Erwinia}

Control measures include;

- Promptly and carefully destroying infected plants and rotted bulbs, corms, rhizomes, tubers, roots, or other affected plant parts when first noticed
- Planting only disease-free planting stock free of cuts and bruises

- Do not plant in poorly drained soil and avoid close planting

- Practice long rotations with crops that are immune, as corn, cereals and grasses.

- Destroy the insects that may aid in disseminating the bacterium, or injure the host.

- Avoid wounding plants when cultivating, digging, handling during and after harvest, packing, and storing (Walker, 1998).

- Harvest during dry weather.

- Store only dry, healthy, mature, blemish-free plants, produce, and storage organs in a clean, dry, well-ventilated area at the recommended temperature and humidity

- If diseased material had been stored previously in store house, such stores should be swept clean and thoroughly sprayed from ceiling to floor with a disinfectant solution like sodium hypo chloride (1000 to $1900 \mathrm{ppm}$ ), and disinfecting of tools by dipping in $70 \%$ alcohol.

\section{CONCLUSION}

Vegetables are highly perishable products, especially during the post-harvest period, storage, transport, retail and at consumer sites (Sharma et al., 2009). Phytopathogens are major causes of postharvest decays of vegetables (Lia, 2009).

Bacterial soft rot caused by the Erwinia spp is one of the destructive diseases of vegetables and occurs worldwide. The pathogen has a wide host range and nearly all fresh vegetables are subject to bacterial soft rots which may develop within a few hours in the field, storage or during marketing (Agrios, 2006), resulting in greater economic losses than any other bacterial disease. The bacteria enter the host tissue through wounds or natural openings and release plant cell wall degrading enzymes such as pectinase and cellulase resulting in the maceration of the plant tissue and decay. Decay is aggravated by high temperature and relative humidity. Control measures include sanitation of packing house, lowering of storage temperature and humidity, harvesting during dry weather, avoiding wounds during harvesting and storage and destroying insects which may transmit the bacterium or injure plants.

\section{REFERENCES}

Agrios, G. N. (1997). Plant pathology (4th ed.). Academic Press, San Diego, California.

Agrios, G.N. (2006). Bacterial Soft Rots.5th Edn., Academic Press, San Diego.

Amadioha, A. C. (1997). Interaction of hydrolytic enzymes produced by Rhizoctania bataticola 
during rot development. Acta phytopathologica Et Entomologica Hungarica 32(1-2): 79-87.

Amadioha, A. C. (2012). Reducing food losses through sustainable methods of plant disease management: an imperative for actualization of food security in Nigeria. A paper presented at the $13^{\text {th }}$ inaugural lecture of MOUAU, June, 2012.

Apeyuan, K.D. (2000). Comparative Susceptibility Of Plant Storage Organs To Soft Rot Bacteria ( $E$. carotovora). M. Sc. Thesis, Ahmadu Bello University, Zaria, 86pp.

Bell KS, Sebaihia M, Pritchard L, Holden MT, Hyman LJ, Holeva MC, Thomson NR, Bentley SD, Churcher LJ, Mungall K, Atkin R, Bason N, Brooks K, Chillingworth T, Clark K, Doggett J, Fraser A, Hance Z, Hauser $H$, Jagels K, Moule S, Norbertczak H, Ormond D, Price C, Quail MA, Sanders M, Walker D, Whitehead S, Salmond GP, Birch PR, Parkhill J, Toth IK. (2004) "Genome sequence of the enterobacterial phytopathogen Erwinia carotovora pv. atroseptica and characterization of virulence factors" Proceedings of the National Academy of Sciences of the United States of America 2004 Jul 27;101 (30):11105-10. Epub 2004 Jul 19

Bradburry, J. F. (1977a). Erwinia carotovora pv. atroseptica. CMI descriptions of pathogenic fungi and bacteria, No551. Kew: Commonwealth Mycological Institute.

Bradburry, J. F. (1977b). Erwinia carotovora pv. carotovora. CMI descriptions of pathogenic fungi and bacteria, No551. Kew: Commonwealth Mycological Institute

Collmer A, Keen NT, (1986). The role of pectic enzymes in plant pathogenesis. Annual Review of Phytopathology 24, 383 - 409.

Czajkowski, R., G. Grzegorz and Van Der Wolf J. M. (2009). Distribution of Dickeya spp. and Pectobacterium carotovorum subsp. carotovorum in naturally infected seed potatoes. Eur. J.Plant. Pathol. 125: 263-275.

Elphinestone, and John G. (2010). "Soft Rot and Blackleg of Potato." Technical Informational Bulletin 21 Aug 1987: 1-8. Web. 26 Oct.

Erinle, I.D (1975). Bacterial rotting of potatoes imported into UK from the Mediterranean region and pathogenicity to stem and tuber by $E$. carotovora, Ph. D., Thesis University of Cambridge, $274 \mathrm{pp}$.

Erinle, I.D (1981). A Short Guide to Bacterial Diseases of Nigeria Plants. Hamdan Press 40 pp.

Garba H. Danladi, Sanusi Muhammad, and Sule S. Manga (2014). Isolation and Identification of Bacteria and Fungi Associated With Rots of Citrullus lanatus and Capsicum frutescence in Sokoto Markets. International Conference on Advances in Agricultural, Biological \& Environmental Sciences (AABES-2014) Oct 1516, 2014 Dubai (UAE).
Gupta, S.K. and Thind, (2006). Diseases of Cruciferous Vegetables. Scientific Publishers, India, pp: 170185.

He'lias V., Andrivon D. and B. Jouan (2000). Development of symptoms caused by Erwinia carotovora ssp. atroseptica under field conditions and their effects on the yield of individual potato plants. Plant Pathology 49, 2332

Howard F. Schwartz and David H. Gent. (2007). Onion Bacterial Soft Rot; High Plains IPM Guide, a cooperative effort of the University of Wyoming, University of Nebraska, Colorado State University and Montana State University.

Hyman, L. J. (1995). Isoenzyme profile and immunological relationships of pectate lyase and polygalacturonase of soft rot Erwinia species. MSc Thesis, University of Dundee.

Ismail, M. E.; Abdel-Monaim, M. F.; and Mostafa, Y. M. (2012). Identification and pathogenic bacteria associated with soft rot disease of girasole tuber in Egypt. Journal of Bacteriology Research Vol. 4(1), pp1-8.

Kharayat, Bhupendra Singh and Singh, Yogendra (2015). Characterization of Erwinia chrysanthemi isolates inciting stalk rot disease of sorghum. African Journal of Agricultural Research. Vol. 10(22), pp. 2309-2314, 28 May, 2015.

Leach, J. G. (1925). The seed corn maggot and potato blackleg. Science 61:120.

Leach, J. G. (1926). The relation of the seed corn maggot (Phorbiafusciceps zett.) to the spread and development of potato blackleg in Minnesota. Phytopathology 16: (149-176), illus.

Leach, J. G. (1927). The relation of insects and weather to the development of heart rot of celery. Phytopathology 17: 663-667, illus.

Leach, J. G. (1930). Potato blackleg: the survival of the pathogen in the soil and some factors influencing infection. Phytopathology 20: 215228, illus.

Leach, J. G. (1933). The method of survival of puparia of the seed corn maggot (Hylemyia cilicrura Rond.) Ztschr. f. Angew. Ent. 20: 150-161, illus.

Lumb VM, Perombelon MCM, Zutra D, (1986). Studies of a wilt disease of the potato plant in Israel caused by Erwinia chrysanthemi. Plant Pathology, 35:196-202.

Nahunnaro H, (2008). Effects of different plant extracts in the control of yam rot induced by Rhizopus stolonifer on stored yam (Dioscorea spp) in Yola, Adamawa State, Nigeria. Medwell J Agric Sci, 3(5):382-387.

Oladoye, C.O.; Olaoye, O. A.; Cornnerton, I. F. (2013). Isolation and identification of bacteria associated with spoilage of sweet potatoes during postharvest storage. Int Agric Food Sci, 3(1):1015 
Okigbo RN, Putheti R, Achusi CT, (2009a). Postharvest deterioration of cassava and its control using extracts of Azadirachta indica and Afromonium meleguata. E-J Chem, 6(4):1274-1280.

Pérombelon MCM, Kelman A, (1980). Ecology of the soft rot Erwinia. Annual Review of Phytopathology 18, 361-87.

Perombelon, M. C. M. (2002). Potato diseases caused by soft rot Erwinia: an overview of pathogenesis. Plant Pathol. 51: 1-12.

Perombelon, M. C. M., Y. Bertheau, M. Cambra, D. Frechon, M.M. Lopez, et al, (1998). Microbiological, immunological and molecular methods suitable for commercial detection and quantification of the blackleg pathogen, Erwinia carotovora pv. atroseptica, on seed potato tubers: A review. Bulletin OEPP. 28:141-155.

Perombelon, M.C.M. (1992) Potato blackleg: epidemiology, host-pathogen interaction and control. Netherlands Journal of Plant Pathology 92, 135-146.

Powelson ML, Franc GD, (2001). Blackleg, aerial stem rot and tuber soft rot. In: Compendium of potato diseases second edition. W.R. Stevenson, R. Loria, G.D. Franc and D.P.Weingartner (eds.) APS Press, St Paul, Minnesota, USA. pp. 10-11. Rahmanifar, B, N. Hasanzadeh, J. Razmi and Ghasemi A. (2012). Genetic diversity of Iranian potato soft rot bacteria based on polymerase chain reaction-restriction fragment length polymorphism (PCR-RFLP) analysis. African J. Biotec. 11(6): 1314-1320.

Thinda, B. S. and Payakab M. M. (1985). A review of bacterial stalk rot of maize in India. Trop. Pest Management. 31:311-316.

Toth, Ian K.; Bell, Kenneth S.; Holeva, Maria C.; Birch, Paul R. J. (2003). "Soft rot erwiniae: from genes to genomes". Molecular Plant Pathology 4 (1): $17-30$

Ugwuoke KI, Onyeke CC, Tsopmbeng NGR, (2008). The efficacy of botanical protectants in the storage of cocoyam (Colocasia esculenta (L.) Schott). Agro-Sci J Trop Agric Food Environ Ext, 7(2):9398.

Wood, M. (1998). Ubi7-new tool for potato breeders. Agricultural Research/January 1998, pp. 12-13. 